\title{
Development of a wound management pathway at a small Rural Health Service
}

\author{
Louine Robinson*, Lisa Pryor, Linda Earl \\ From Australasian Podiatry Conference 2015 \\ Queensland, Australia. 6-8 May 2015
}

\section{Background}

Beechworth Health Service (BHS) formed a Wound Management Working Party (WMWP) in 2011 to improve wound management and client outcomes. Existing expertise and systems were utiliized in conjunction with public and private agencies to ensure best practice and continuity of care for acute, aged care and community clients.

\section{Process}

The WMWP consisted of executive, allied health, unit managers, accounts and clinical staff to ensure the committee had organisation wide buy-in and could act on recommendations made. In 2012, BHS partnered with an industry consultative Wounds Improvement Program to review current systems and conduct a wound prevalence audit of acute, residential and community clients. A report of recommendations was produced which included: standardisation of procedures; policies; wound products; documentation; an education program for all staff involved in wound care to support change and embed new practice. The report recommendations were implemented early 2013. Additional education and resources were accessed from the Victorian Department of Health initiative, Connected Wound Care program. As the wound management pathway became formalised at BHS, it was recognised the working party's role was finished and the Wound Management Committee (WMC) took over monitoring and reviewing the wound management pathway. The organisation wide audit is now conducted annually. There have been 3 to date.

\section{Findings}

The partnership with industry has resulted in improved client and organisational outcomes. The results of the

* Correspondence: Louine.Robinson@bhs.hume.org.au Beechworth Health Service, Beechworth, VIC, 3747, Australia
2014 wound prevalence audit found that the incidence and severity of wounds had decreased since 2012 .

\section{Conclusions}

The establishment of a partnership with BHS and industry through the Wound Improvement Program has been shown to improve wound management outcomes. Small Rural Health Services can utilise resources from public and private sectors that can facilitate the delivery of best practice wound care. The use of common resources has: facilitated a regionally consistent message and care to clients; created networks between health services in the Hume region formalised in the Wounds in Hume Improvement Committee.

Published: 22 September 2015

doi:10.1186/1757-1146-8-S2-P14

Cite this article as: Robinson et al:: Development of a wound

management pathway at a small Rural Health Service. Journal of Foot and Ankle Research 2015 8(Suppl 2):P14.

Submit your next manuscript to BioMed Central and take full advantage of:

- Convenient online submission

- Thorough peer review

- No space constraints or color figure charges

- Immediate publication on acceptance

- Inclusion in PubMed, CAS, Scopus and Google Scholar

- Research which is freely available for redistribution

Submit your manuscript at www.biomedcentral.com/submit
() Biomed Central 